\title{
The Impact of Workplace Environment, Motivation and Workplace discipline on Employees' Performance of Local Water Supply Utility at Sikka Regency, Indonesia
}

\author{
Viktor Eko Transilvanus ${ }^{1}$, Junianto Tjahjo Darsono ${ }^{2}$ and Tanto Gatot Sumarsono ${ }^{3}$ \\ ${ }^{1}$ Student in Master in Management Program, University of Merdeka Malang, Indonesia \\ ${ }^{2,3}$ Faculty Economics and Business, University of Merdeka Malang \\ Indonesia
}

\begin{abstract}
This study has the following aims: (1) to describe the working environment, motivation, working discipline and employees' performance; (2) to analyze the influence of working environment (X1), motivation (X2, and working discipline (X3) on employees' performance (Y); and (4) to examine the variables that have dominant influence towards the employees 'performance of Local Water Supply Utility at Sikka Regency, East Nusa Tenggara Province. This study used 81 respondents. The analysis technique used is the multiple regression analysis, F test, and t-test. The descriptive results of statistics showed that the workplace environment was formed by the following things: lighting, air temperature and air circulation, color, music, and working security. The main thing that supported the workplace environment was the air temperature with an average value between 4.28 to 4.36 . The air temperature setting was proven to be the best since it made the room felt fresh. Next, motivation was formed by the following needs: physiological, safety, social, appreciation, and self-actualization. The main thing that built motivation was social need, reward need, and self-actualization need of with an average value of 4.42 for each need. Furthermore, the needs were reflected as follows: the presence of leaving permission owned by employees (4.51), the Leader gave an award for the work that had been performed well (4.47), and the Leader gave an opportunity for promotion (4.51). Meanwhile, the workplace discipline was formed by attendance, compliance attitude with work standards, adherence attitude on work rules and work ethics. The main thing that could improve workplace discipline was an adherence attitude on company's rules with an average value of 4.4 . It was reflected from employees' willingness to use the prearranged uniform set (4.53). Furthermore, employee performance was shaped by the quality of work, quantity of work, punctuality, effectiveness, independence and work commitment. The main thing that could improve employees' performance was the effectiveness with an average value of 4.43.It was depicted by how the respondents utilizing their time in completing their tasks (4.49). The workplace environment, motivation, and workplace discipline were shaping the employees' performance of Local Water Supply Utility (PDAM) at Sikka Regency, East Nusa Tenggara Province. Thus, it could be concluded that good workplace environment which was supported by employees who had high motivation, and high workplace discipline to work in compliance with applicable rules and regulations, definitely could improve employees' performance. Motivation influenced the likelihood of employees' performance of Local Water Supply Utility (PDAM) at Sikka Regency, East Nusa Tenggara Province. This showed that the main thing that could improve employees' performance was motivation.
\end{abstract}

Key Words: Workplace Environment, Motivation, Workplace Discipline, Employees Performance.

\section{INTRODUCTION}

Performance according to Mangkunegara (2010: 67) (cite by reference number) is the result of working both qualitatively and quantitatively which is achieved by an employee by carrying out his duties in accordance with the responsibilities given to him. Furthermore, according to Siagian (2012: 89), employees' performance is influenced by several factors, namely: salary, workplace environment, organizational culture, leadership and workplace motivation (or simply just motivation), workplace discipline, job satisfaction, and communication factors. Meanwhile, this study discusses only the workplace environment, motivation, and workplace discipline. 
The workplace environment according to Rahmawati (2011: 122) is everything existed around workers that can influence them in carrying out the tasks assigned to them. A good, safe, clean and healthy workplace environment will make employees feel safe and comfortable in carrying out the tasks assigned to them. The workplace environment focuses on the physical state of the workplace. Workplace environment indicators include room, air temperature and noise. From this understanding, the workplace environment can affect the performance of employees at work.

Motivation is one of the factors that drive employees' performance. According to Robbins and Judge (2008: 222), motivation is a process that explains the intensity, direction and perseverance of an individual to achieve his goals. Motivation is a psychological factor that shows about an individual's interest of his work, individual's satisfaction feeling and individual's responsibility in carrying out the activities or the ongoing work. A person's behavior is motivated by the desire to obtain certain goals. Motivation is an important thing to note, due to the presence of motivation, an employee can have high enthusiasm in carrying out the tasks being charged. Without motivation, an employee will not be able to fulfill his duties properly, and later on, the result of his work will not be satisfying too.

Furthermore, the workplace discipline can also affect employees' performance. The discipline that is owned, both by the management / leaders and employees of the company since company's establishment until present time can work as a prove for company's excellence in the competitive era of today's globalization. Moreover, Rivai (2008: 444) also states that workplace discipline is a tool used by managers to communicate with employees so that employees are willing to change their misplaced behavior. It is also worked as an effort to increase employees' awareness and willingness to comply with all applicable company regulations and social norms. Without discipline, all of the company's activities being carried out will bring unsatisfactory results and are not in line with expectations. Discipline is a form of training that enforces company regulations. The expected discipline is a discipline in implementing working system which is regulated and listed in the work system regulations set by the company.

From the description above, it can be inferred that it is very important to pay attention on employees in order to manifests good services for consumers / customers in an effective, efficient, professional, and productive way. Thus, it is necessary to formulate a detailed and integrated effort that should be made to achieve optimal performance, by knowing the factors that significantly influence the employees 'performance of Local Water Supply Utility (PDAM) at Sikka Regency, East Nusa Tenggara Province. Furthermore, leaders and related parties will gain an ease in determining the steps for coaching the organization.

The Sikka Regency Government of East Nusa Tenggara Province apparently has lack of efforts in improving their employees' performance, especially in the Local Water Supply Utility (PDAM), such as the level of community service that did not provide benefit for community's benefit. Furthermore, the employees of Sikka Regency Government in East Nusa Tenggara have not yet achieved optimal results where many employees could not complete the obligation to work on time. They could not achieve the predetermined work targets, and also have lack of willingness to complete their work with good results. Moreover, the employees of Local Water Supply Utility (PDAM) at Sikka Regency in East Nusa Tenggara Province are less than able to use the available working time optimally. They work under the assumption that either doing the job well or doing the job poorly, they would still get the same salary. The employees are still having lack of willingness on themselves that the tasks and responsibilities given on them should be completed by employing maximum efforts to achieve the organizational goals.

The working environment in the Local Water Supply Utility (PDAM) at Sikka Regency, East Nusa Tenggara Province still requires a lot of improvement. Some of the rooms seem having lack of lighting equipment. The office runs out of color of the room that could produce calm feeling. Talking about tidiness, the office arrangement is still not optimal too, because researchers could still find the untidy area.

In addition, the level of attendance of the employees Local Water Supply Utility (PDAM) at Sikka Regency, East Nusa Tenggara Province has been fluctuated. It seems that the employees are not yet fully taking discipline, such as coming to work as part of their working obligation without any coercion. Next, the working rotation of the employees also happens too fast. On the other hand, for the punctuality presence of the employees, some of the mare coming on time to the office but some of them chose to come late.

Furthermore, as researchers observe the Local Water Supply Utility (PDAM) of Sikka Regency, East Nusa Tenggara Province, the act of giving motivation, such as giving awards to employees who excel and also providing opportunities to continue their studies is still not very visible. Thus, employees are not motivated to develop the skills that they possessed. For creativity in carrying out the office duties, the employees still have not received adequate attention because employees have a tendency to just carry out their tasks without improvement.

It could be inferred that the employees' performance of the Local Water Supply Utility (PDAM) alsike Regency, East Nusa Tenggara Province is still not optimal. The different level of ability and interest that are in contrast with the current tasks triggers the un-optimum working performance. Moreover, in terms of working quantity and quality that includes the standard use of time, the employees' performance still requires a further improvement. 
In 2015, Noviyanti shows in her research that work motivation, workplace environment, and workplace discipline simultaneously have a significant effect on the employees' performance of the Central Sulawesi Provincial BAPPEDA office. Each of the factor shares the same amount of significant effect towards the performance of the Central Sulawesi Provincial BAPPEDA office.

The purposes of this study are as follows:(1) to describe the workplace environment, motivation, workplace discipline, and employees' performance Local Water Supply Utility (PDAM) at Sikka Regency, East Nusa Tenggara Province; (2) to analyze the influence of workplace environment (X1), motivation (X2) and workplace discipline (X3) on employees' performance (Y); and (3) to analyze variables that have a dominant influence on the employees' performance of Local Water Supply Utility (PDAM) at Sikka Regency, East Nusa Tenggara Province.

\section{LITERATURE REVIEW}

\subsection{Performance}

According to Mangkunegara (2016: 67), the term Performance comes from the word job performance or Actual Performance (work performance or actual accomplishment achieved by someone). The definition of Performance is the result of work both in quality and quantity. It is achieved when an employee carrying out his duties which are in accordance with the responsibilities given to him. Performance is the result of a process that drives an individual employee and is measured over a period of time based on a predetermined provision or agreement (Edison 2016: 190)

\subsection{Workplace environment}

According to Sedarmayanti (2017: 25), the workplace environment is: "The entire tools or equipment and the facing materials; the surrounding environment in which a person works; the method of work; and the work arrangements both as individuals and as a group". In addition, Nitisemito (2009: 183) also says that the workplace environment is: "Everything that is around the workers that can influence them in completing the tasks they are carrying out".

\subsection{Motivation}

Hasibuan (2010: 143) states that motivation as a driving force that creates the excitement of employees' work so that they will cooperate, work effectively, and be able to be integrated with all of their efforts to achieve satisfaction. Motivation measures the size of one's effort, whether he tries or works hard to achieve his needs or not. In other words, someone with low motivation will never achieve results beyond the strength of his motivation. Next, Sutrisno (2011: 109) affirms that "Motivation is a factor that encourages a person to do a certain activity". While Handoko (2001: 9) argues that: "Motivation is a force or factor inside human beings that raises, moves and organizes behavior".

\subsection{Workplace discipline}

Hasibuan (2017: 193) declares that discipline is the awareness and willingness of someone to obey all of company regulations and be aware of their duties and responsibilities, while willingness is an attitude, behavior, actions of someone who is in accordance with the company rules both written and spoken. According to Singodimedjo in (Sutrisno, 2015; 86) discipline is an attitude of willingness and willingness to obey and adhere the norms that apply around it. A good employee discipline will accelerate company goals, while a degrading discipline will be a hindrance and slow down the achievement of company goals.

\subsection{Hypothesis}

1. Workplace environment, motivation and workplace discipline havesignificant impacton employees' performance of Local Water Supply Utility (PDAM) at Sikka Regency, East Nusa Tenggara Province.

2. Motivation has dominant influemce on employees' performance Local Water Supply Utility (PDAM) at Sikka Regency, East Nusa Tenggara Province.

\section{METHOD}

\subsection{The Operational Definition of Variables}

\section{a. Performance (Y)}

Performance was the result of work in quality and quantity achieved by an employee in carrying out his duties which was in accordance with the responsibilities given to him. The indicators were as follows: quality of work (y1.1), quantity of work (y1.2), punctuality of work (y1.3), effectiveness (y1.4), independence (y1.5) and work commitment (Y1.6) 
International Journal of Advances in Scientific Research and Engineering (ijasre), Vol 5 (4), April-2019

\section{b. Workplace environment (X1)}

The workplace environment was a situation or condition around the employees. The indicators were as follows: lighting, air temperature, air circulation, color, and security at workplace.

\section{c. Motivation (X2)}

Motivation was the factor that existed within a person who moved and directed their behavior to meet certain goals. The indicators were as follows: physiological need (x2.1), safety need (x 2.2), social need (x2.3), reward need (x2.4), and last the need for self-realization (X2.5)

\section{d. Workplace discipline (X3)}

Workplace discipline was the attitude of obedience, compliance, and sincerity of employees carrying out their obligations and responsibilities which was in accordance with company's applicable rules and regulations. The indicators were as follows: attendance frequency (x3.1), adherence to work standards (x3.2), adherence to work rules (x3.3) and work ethics (X3.4)

\subsection{Population and Sampling Techniques}

The population in this study were the employees of Local Water Supply Utility (PDAM) at Sikka Regency, East Nusa Tenggara Province. There were 81 employees. All of the employees were used as sample. The sampling technique being used in this study was the saturated sampling.

\subsection{Data analysis technique}

\section{a. Descriptive Analysis}

In this study, the descriptive analysis technique was used to describe motivation, workplace environment, workplace discipline, and employee performance. For this reason, descriptive statistics were utilized to find the calculated average (mean), and the standard deviation of the variants.

\section{b. Multiple Linear Regression Analysis}

The multiple linear regression analysis was used to determine the effect of independent variables on the dependent variable, also used to make predictions on employee performance:

$\mathrm{Y}=\mathrm{a}+\mathrm{b}_{1} \mathrm{X}_{1}+\mathrm{b}_{2} \mathrm{X}_{2}+\mathrm{b}_{3} \mathrm{X}_{3}+\mathrm{e}$

Where:

$\mathrm{Y}=$ Performance

$\mathrm{a}=$ constant number

$\mathrm{b}=$ Regression coefficient

$\mathrm{X}_{1}=$ Workplace environment

$\mathrm{X}_{2}=$ Motivation

$\mathrm{X}_{3}=$ Workplace discipline

$\mathrm{e}=$ error

\section{RESEARCH RESULT}

\subsection{Multiple Regression Analysis}

From the results of data processing using the computer assistance program SPSS 15 for windows, the results of the analysis are obtained as in the following table:

Table 1. The Recapitulation Results of Multiple Linear Regression Analysis 
International Journal of Advances in Scientific Research and Engineering (ijasre), Vol 5 (4), April-2019

\begin{tabular}{|c|c|c|c|c|}
\hline Variables & Regression Coefficient & $\mathbf{T}_{\text {count }}$ & Sig. & Note \\
\hline $\begin{array}{l}\text { Workplace Environment }\left(\mathbf{X}_{1}\right) \\
\text { Motivation }\left(\mathbf{X}_{2}\right) \\
\text { Workplace Discipline }\left(\mathbf{X}_{3}\right)\end{array}$ & $\begin{array}{l}0,190 \\
0,454 \\
0,171 \\
\end{array}$ & $\begin{array}{l}2,471 \\
5,125 \\
2,167 \\
\end{array}$ & $\begin{array}{l}\mathbf{0 , 0 1 6} \\
\mathbf{0 , 0 0 0} \\
\mathbf{0 , 0 3 3} \\
\end{array}$ & $\begin{array}{l}\text { Significant } \\
\text { Significant } \\
\text { Significant }\end{array}$ \\
\hline $\begin{array}{l}\text { Constant } \\
\mathrm{R} \\
\text { Adjusted } R \text { square } \\
\mathrm{F}_{\text {count }} \\
\text { Sig. F } \\
\mathrm{n}\end{array}$ & $\begin{array}{r}0,849 \\
0,737 \\
0,526 \\
30,598 \\
0,000 \\
81 \\
\end{array}$ & & & \\
\hline \multicolumn{5}{|c|}{ Dependent variable = Employees' Performance $(\mathrm{Y})$} \\
\hline $\begin{array}{l}\mathrm{F} \text { table }=2,72 \\
\mathrm{t} \text { table }=2,000\end{array}$ & & & & \\
\hline
\end{tabular}

Based on the recapitulation table, the multiple regression equation obtained was as follows:

$\mathrm{Y}=0.849+0.190 \mathrm{X} 1+0.454 \mathrm{X} 2+0.171 \mathrm{X} 3$

Furthermore, the explanation can be seen below:

$\alpha=0.849$ was a constant which meant that if all of the independent variables: the workplace environment (X1), motivation (X2), and workplace discipline (X3) were 0 , then the variable of employees' performance was 0.849 .

$\beta 1=0,190$ was the magnitude of the independent variable regression coefficient of workplace environment (X1).It had a positive sign indicating that the workplace environment had a direct effect on employees' performance. It meant that a better workplace environment would increase employees' performance. In addition, it was done by assuming that the motivation (X2) and workplace discipline (X3) variables were having fixed amount. While the influence of the workplace environment on employee performance was 0.190

$\beta 2=0.454$ was the magnitude of the motivation independent variable regression coefficient (X2). It had a positive sign indicating that motivation had a direct effect on employees' performance. Thus, the better the motivation, the higher number of employees' performance would be. It was conducted under the presumption that the workplace environment (X1), and workplace discipline (X3) variables were having fixed amount. While the influence of motivation on employees' performance was 0.454 .

$\beta 3=0.171$ was the magnitude of the independent variable of workplace discipline regression coefficient (X3).It had a positive sign that the workplace discipline possessed a direct effect on employees' performance. It signified that a better motivation would increase employees' performance. It was under the assumption that the workplace environment (X1) and motivation (X2) were having variables fixed amount. Meanwhile, the influence of workplace discipline on employees' performance was 0.288 .

The multiple correlation coefficient $(\mathrm{R})$ was 0.737 . It indicated a strong relationship between workplace environment (X1), motivation (X2), and workplace discipline (X3) together with employees' performance (Y). The value of determination coefficient (Adjusted R square) was 0.526. This coefficient of determination meant that the workplace environment (X1), motivation (X2), and workplace discipline (X3) were together able to contribute to employees' performance by $52.6 \%$, while the remaining $47.4 \%$ was caused by other variables which was not included in the study.

\subsection{Hypothesis Testing}

\section{a. Testing the First Hypothesis}

To test the first hypothesis which stated that the workplace environment, motivation and workplace discipline significantly influenced the employees' performance of Local Water Supply Utility (PDAM) at Sikka Regency, East Nusa Tenggara Province, researchers used the $\mathrm{F}$ test and $\mathrm{t}$ test. From the results of the calculation of multiple regression analysis with SPSS, the obtained results were as follows: $F_{\text {count }}$ of 30.598 , was less than $F_{\text {table }}$ at $a=5 \%$, df1 $=3$, and df $2=56$ of 2.72. This meant that $F_{\text {count }}>F_{\text {table }}$ $(30,598)>2,72)$ while the probability value was smaller than $\mathrm{a}=0,05(0,000<0,05)$. Then Ho was rejected and Ha was accepted which meant that the independent variables (workplace environment, motivation, and workplace discipline) simultaneously had a significant impact on employees' performance.

1) The results of the $t$ test of the workplace environment variable obtained $t_{\text {count }}=2.471$ while the value of $t_{\text {table }}=2,000$ so that $\mathrm{t}_{\text {count }}>\mathrm{t}_{\text {table }}$ or the significance value was $0.016<0.05$. Thus, Ho was rejected or Ha was accepted, and it was proven that the work place environment variable (X1) had a significant effect on employee performance (Y).

2) The results of the $t$ test were obtaining the value of $t_{\text {count }}=5.125$ while the value of $t_{\text {table }}=2,000$ so that $t_{\text {count }}>t_{\text {table }}$ or the significance value was $0,000<0.05$. Thus, Ho was rejected or Ha was accepted, and it was proven that the motivation variable (X2) had a significant effect on employees' performance (Y). 
3) The results of the $t$ test were obtaining the value of $t_{\text {count }}=2.167$ while the value of $t_{\text {table }}=2,000$ so that $t_{\text {count }}>t_{\text {table }}$ or the significance value was $0.033<0.05$. Therefore, Ho was rejected or Ha was accepted, and it was proven that the workplace discipline variable (X3) had a significant effect on employees' performance (Y).

Based on the results of the $\mathrm{F}$ test and t test, it could be inferred that the workplace environment, motivation, and workplace discipline were either simultaneously or partially had a significant effect on employees' performance. Thus, the first hypothesis was statistically accepted or tested.

\section{b. Testing the Second Hypothesis}

Researchers looked at the magnitude of the regression coefficient that had a significant effect on employees' performance to test the second hypothesis which stated that motivation had a dominant influence on the employees' performance of Local Water Supply Utility (PDAM) at Sikka Regency, East Nusa Tenggara Province. Based on the results of the t test, it could be inferred that the workplace environment, motivation, and workplace discipline partially had a significant effect on employees' performance (Y). Whereas to find out the variable that had the dominant influence, researchers looked at the magnitude of the regression coefficient that had a significant effect on employees' performance. The independent variable which had the largest and most significant coefficient was the variable which owned the dominant influence on employees' performance. Based on the results of multiple regression analysis, it could be concluded that the biggest regression coefficient was motivation by 0.480. It signified that motivation was a variable that had a dominant influence on employees' performance. Thus, both of the hypotheses were statistically acceptable or tested.

\section{DISCUSSION}

\subsection{The Description of Workplace Environment, Motivation, Workplace Discipline and Employees' Performance}

The workplace environment was formed by lighting, air temperature, air circulation, color, music, and work security at the workplace. The main thing that supported the workplace environment was the air temperature at the workplace with an average value of 4.28. The average value for fresh room was marked with the value of 4.36. A conducive workplace environment made employees feeling comfortable and safe in completing their work. It was in accordance with Sedarmayanti's (2010: 1) opinion. She said that the workplace environment was consisted as follows: the entire tools/equipment and materials being faced, the surrounding environment in which a person performed his work, the method of work, and employees' working arrangement, both as individuals and as a group.

Motivation was formed by physiological need, safety need, social need, appreciation need and self-actualization need. The main thing that built motivation was social need, rewards need, and the self-actualization need, each was having an average value of 4.42. The needs were reflected from the following things: the employees receiving leave permission (4.51); the leader gave an award for the work that had been performed well (4.47); and the leader gave an opportunity for promotion (4,51). Motivation was an impulse within employees' selves to increase their own enthusiasm and passion to work in accordance with what was desired by the leader as an effort to achieve company goals. The result was in line with Hasibuan's (2010: 143) opinion. He stated that motivation was a driving force to create the excitement of one's work performance so that they would be willing to cooperate, work effectively, and be integrated with all their efforts to achieve satisfaction

Furthermore, the workplace discipline was formed by attendance, compliance with work standards, adherence to work rules and work ethics. The main thing that could improve workplace discipline was an adherence to the rules of cooperation with an average value of 4.43. The value was reflected from employees' willingness to use the set of uniforms that had been arranged (4.53). Workplace discipline was an attitude shown by the employees' willingness to comply with existing rules and regulations and the employees' sincerity in carrying out obligations and responsibilities in accordance with company's policy. It was in accordance with Hasibuan's (2014: 77) statement. He said that discipline was an awareness and willingness of someone to obey all of company regulations and prevailing social norms.

Employees' performance was formed by the quality, quantity, punctuality, effectiveness, independence, and commitment of work. The main thing that could accelerate employees' performance was the effectiveness with an average value of 4.43 . It was shown by respondents' response in utilizing to carry out their work (4.49). Furthermore, the effectiveness could be achieved if the work was carried out in accordance with the conditions required by the job. The company always strived hard so that every employee involved in the company could achieve the work effectiveness well. The success of the company in achieving its goals starting with the success of each employee. Company's success could be accomplished if each employee could achieve the desired 
goals. A job was said to be effective if it could achieve the planned goals and by using all the resources that had been organized by the company. As stated Mangkunegara's (2010: 67) before, performance was the work of quality and quantity achieved by an employee in carrying out his duties which was in accordance with responsibility given to the employee.

\subsection{The Impact of Workplace Environment on Employees' Performance}

The workplace environment had an impact on employees' performance. If the created corporate environment paid an attention towards workplace environment aspects which included lighting, air temperature, air circulation, color, music, and security in the workplace, the objectives to achieve high employees' performance would be achieved. Furthermore, in the long period, it could improve employees' performance too. The workplace environment indicator that made the biggest contribution in improving employees' performance was the air temperature in the workplace with an average value of 4.28. The existence of a conducive workplace environment could provide a sense of comfort for the employees. Thus, they would try to always give the best results for the company. It was in line with Kasmir's (2016) finding which stated that one of the factors that influence performance was the workplace environment.

\subsection{The Impact of Motivation on Employees' Performance}

Motivation influenced employees' performance, and it was a variable that had the dominant influence on employees' performance. Therefore, it could be defined that the higher the motivation of the employees, the higher will be the improvement of employees' performance. Motivation was a psychological factor. It showed the employee's interest in the job, employees' satisfaction feeling, and employees' responsibility for carrying out the activities or work. Employees' behavior was motivated by the desire to achieve goals. Motivation was an important thing is taken into account because it helped employees to have high enthusiasm in carrying out the tasks charged. The indicator of motivation that gave the biggest contribution in improving employees' performance was social need, the need for reward, and the actualization need with an average value of 4.42 for each need. Without motivation, an employee would not be able to fulfill the obligations and duties given by the leader that possibly ended up with unsatisfying work results. Kasmir (2016) uttered that one of the factors that influenced employees' performance was work motivation. Work motivation was a form of encouragement for employees to do his work. If the employee had a strong drive from within or got an encouragement outside himself (for example from the company), then the employee would feel encouraged to do his work well. The results of this study were in accordance with the statements from Hidayat (2012), Hardjono (2013), Novyanti (2015), and Susitianingrum (2015) defining motivation affected performance.

\subsection{The Effect of Workplace Discipline on Employees' Performance}

Workplace discipline affected employees' performance. It meant that the higher the level of workplace discipline owned by employees, the higher the employees' performance would be also. In 2016, Kashmir said that one of the factors influencing employees' performance was workplace discipline. It was an effort given by employees to carry out the work activities in the company earnestly. The workplace discipline indicator that provided the greatest contribution to improve employees' performance was an adherence behavior on company's rules with an average value of 4.43 . In this case, the workplace discipline was measured using time factor, for example, an employee should come to work on time. The existence of workplace discipline was very necessary in a company because it helped the company to carry out its work programs in achieving the previously established goals. Employees who were discipline and obeyed all of the norms and regulations that were applied in the company would be able to improve their efficiency, effectiveness, and performance. Without workplace discipline, the company would find difficulty to achieve its previously organized goals. The results of this study were in accordance with the opinions of Hidayat (2012), Hardjono (2013), Novyanti (2015), Susitianingrum (2015), and Amiro (2015) stating that workplace discipline affected employees' performance.

\section{CONCLUSION}

The descriptive results of statistics portray that the workplace environment is formed by the followings: lighting, air temperature, air circulation, color, music, and safety. The main thing that supports the workplace environment is the air temperature with an average value of 4.28. It is reflected with an average value of 4.36 for the factor of fresh air. Motivation is shaped by several needs. They are physiological need, security and safety need, social need, appreciation need, and selfactualization need. The main things that developed motivation are social need, reward need, and the actualization needs with an average value of 4.42 for each need. It was reflected namely from: employees are getting leaving permission (4.51); the Leader rewards the work that has been done well (4.47); and the Leader provides opportunities for promotion (4.51). Workplace discipline is formed by: attendance; a compliance to work according to standards; an adherence to work based on rules and work ethics. The main thing that can improve workplace discipline is an adherence to company's rules with an average value of 4.43 . It 
is shown by employees 'willingness to use the uniform (4.53). Employees' performance is shaped by the quality of work, quantity of work, punctuality, effectiveness, independence and work commitment. The main thing that can improve employee performance is the effectiveness with an average value of 4.43 as reflected by the respondents' response in utilizing the time to accomplish their work (4.49).

The work environment, motivation and workplace discipline influence the employees' performance of Local Water Supply Utility (PDAM) at Sikka Regency, East Nusa Tenggara Province. It means conducive workplace environment supported by employees who have high work motivation, and high workplace discipline to work in compliance with applicable rules and regulations can improve employees' performance.

Motivation has a dominant influence on employees' performance of Local Water Supply Utility (PDAM) at Sikka Regency, East Nusa Tenggara Province. This shows that the main thing to leverage the employees' performance of Local Water Supply Utility (PDAM) at Sikka Regency, East Nusa Tenggara Province is motivation.

\section{SUGGESTION}

A company should always provide a sense of security and comfort for employees so that employees' performance could be increased. Furthermore, to make employees feeling motivated at workplace, company should provide retirement benefits which is in accordance with applicable regulations. It is best advised for company to give a well-established guideline to raise employees' workplace discipline in completing their tasks. Last, for further research, it is expected that future researchers are able to develop research by employing other independent variables, such as leadership style and ability. Thus, it can provide a better point of view in understanding leader's influence on employees' performance.

\section{REFERENCES}

1. Edy Sutrisno, 2011. Human Resource Management. Kencana Pernada Media Group. Jakarta.

2. Hasibuan, Malayu. S.P 2014. Human Resource Management (Revised Edition). EarthAkara. Jakarta.

3. Basic Organization and Motivation for Increasing Productivity. 5th edition.2010, Bumi Aksara, Jakarta.

4. Edison, Emron, Anwar, Yohny and Komariyah, Imas. 2016. Human Resources Management. 1st print. Alfabeta. Bandung.

5. Handoko.T.Hani.2001. Personnel and Human Resources Management, Edition II. BPFE Yogyakarta: Yogyakarta

6. Jajang Amiro. 2015. Effect of Discipline, Work Environment, Organizational Culture and Competence on Worker Performance through Motivation, Job Satisfaction (Study at the Regional Development Planning Board of Sukoharjo Regency). Master Management Study Program, STIE I ADI UNGGUL BHIRAWA "Surakarta. European Journal of Business and Management www.iiste.org ISSN 2222-1905 (Paper) ISSN 2222-2839 (Online) Vol.7, No.36, 2015 ...

7. Joyce Sagita Novyanti. 2015. Effect of Work Motivation, Work Environment and Work Discipline on Employee Performance at the Central Sulawesi Province BAPPEDA. Journal. Master of Management Study Program Postgraduate of Tadulako University.

8. Mangkunegara, Anwar Prabu. 2015. Performance Evaluation. Second edition. Refika Aditama. Bandung.

9. Robbins and Judge. 2015. Organizational Behavior. Salemba Empat. Jakarta.

10. Sedarmayanti.2011. Human Resource Management Bureaucratic Reform and Management of Civil Servants. Refka Aditama. Bandung.

11. Human Resources and Work Productivity. Second edition.2015, Mandar Maju, Bandung.

12. Siagian, Sondang P.2014. Human Resource Management. Jakarta: BumiAksara.

13. Tri Hardjono. 2013. Analysis of the Effect of Motivation, Work Discipline and Job Ability on the Performance of Civil Servants Empirical Study in Mijen District, Semarang City). Journal. Postgraduate Program in Management Master of Dian Nuswantoro University Semarang. 